\title{
Role of murine macrophages and complement in experimental campylobacter infection
}

\author{
W. BÄR
}

Institute of Medical Microbiology, Johannes Gutenberg University of Mainz, Hochhaus am Augustusplatz, 6500 Mainz, FRG

\begin{abstract}
Summary. The roles of macrophages and the complement system as potential host defence mechanisms in mice against campylobacter infection were studied in vivo, by depleting the murine serum-complement or the phagocytic cells. Macrophagedepletion was performed by intraperitoneal (i.p.) injection of silica dust, Liquoid or dextran sulphate. During 5 days after infection, such mice showed a significant increase in mortality, compared with controls. In contrast, mice that were previously decomplemented by i.p. injection of Cobra Venom Factor showed no significant increase in mortality. The results with combined macrophage depletion and decomplementation did not differ from those with macrophage depletion alone. These experiments suggest that macrophages seem to be more important than complement in the defence of mice against experimental campylobacter infection.
\end{abstract}

\section{Introduction}

Campylobacter jejuni is recognised as a major cause of human enteritis (Skirrow, 1977). In order to study virulence factors, many workers have tried to establish an in-vivo model for campylobacter infection; however, a suitable animal model has not been found (a list of investigated models was summarised by Fox, 1982).

Mice, like other animals, are fairly resistant to campylobacter infection (Blaser et al., 1983) and develop signs of disease, which resemble human campylobacteriosis, only when receiving very high doses (Humphrey et al., 1986; McCardell et al., 1986). Adult mice, infected orally with $10^{8}$ bacteria, became excreters; and, in histological preparations, acute inflammatory reactions were observed (Blaser et al., 1983). However, neonatal mice, infected with higher doses of bacteria, showed severe symptoms of infection such as diarrhoea and increased mortality (Madge, 1980; Kazmi et al., 1984). It was concluded that, although mice may be susceptible to campylobacter infection, a highly effective immune mechanism prevents adult mice from becoming seriously affected.

The observations that mice are quite resistant, even on first contact with Campylobacter spp., leads to the assumption that nonspecific defence mechanisms such as the complement system or mono-

Received 23 Apr. 1987; revised version accepted 16 Sep. 1987. nuclear phagocytes might contribute to the host's resistance. Several in-vitro studies support this view : $C$. jejuni and $C$. coli are reported to be serumsensitive (Blaser et al., 1985), thus emphasising a possible role for complement as a potential defence mechanism in tissue and in the circulation. Furthermore, phagocytosis of $C$. jejuni by mononuclear phagocytes has been demonstrated (Kiehlbauch $e t$ al., 1985; Banfi et al., 1986), indicating a contribution of the macrophage (MØ) to the defence mechanism.

The purpose of this study was to examine in vivo the role of nonspecific humoral and cellular immune mechanisms. The protective effect was assessed by reducing the murine complement system or the phagocytic cells systemically, and then studying susceptibility to infection with $C$. jejuni. In-vivo decomplementation was performed by injecting Cobra Venom Factor (CVF), mainly affecting serum-C3 (Cochrane et al., 1970). Macrophagedepletion was achieved by injecting silica dust or polyanions-dextran sulphate or Liquoid (Bloksma et al., 1980).

\section{Materials and methods}

\section{Mice}

Female NMRI mice (from Ivanovas Versuchstierzuchtanstalt, Kieslegg, FRG) were used at 4-6 weeks of age. They were kept in groups of 4-6 per cage, and were 
given antibiotic-free food and water ad libidum. From each animal, a faecal specimen was obtained and cultured for Campylobacter spp. before the study, but no positive cultures resulted.

\section{Strain of Campylobacter}

The strain was a clinical isolate from a patient with diarrhoea. It was grown in a micro-aerophilic and capnophilic atmosphere at $37^{\circ} \mathrm{C}$ on Columbia Agar supplemented with laked horse blood $5 \%$. The isolate was identified as $C$. jejuni by the following criteria: typical microscopic appearance, oxidase and catalase positive, sensitive to nalidixic acid, growth at $43^{\circ} \mathrm{C}$, hippurate positive.

\section{Intraperitoneal and oral challenge}

Overnight cultures of bacteria were washed once with sterile saline, resuspended in phosphate-buffered saline

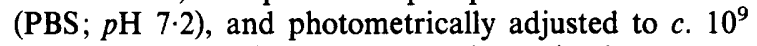
bacteria/ml. The viable count was determined retrospectively by culture of serial tenfold dilutions on agar plates. Mice were infected either i.p., by injecting $0.5 \mathrm{ml}$ of bacterial suspension into the abdominal cavity, or orally, by introducing $0.5 \mathrm{ml}$ into the stomach with a plastic feeding tube (Boak Cannula 12"; Portex Ltd, Hythe). To preserve the virulence of the infecting strain, organisms were recovered from moribund or recently dead mice.

\section{Determination of serum-sensitivity}

Serum-sensitivity was tested as described by Blaser $e t$ al. (1985), except that $90 \%$ mouse serum was used in these experiments.

\section{Decomplementation by Cobra Venom Factor (CVF)}

CVF (Miami Serpentarium Laboratories, FL, USA) was purified as described by Bitter-Suermann et al. (1972) and stored at $-70^{\circ} \mathrm{C}$. Mice received $5 \mu \mathrm{g}$ of $\mathrm{CVF}$, dissolved in $0.5 \mathrm{ml}$ of saline, by i.p. injection $12 \mathrm{~h}$ and $24 \mathrm{~h}$ before challenge (see also table I).

Monitoring CVF-induced decomplementation. CVF-induced decomplementation was shown by monitoring the serum C3 levels by rocket-immuno-electrophoresis (Laurell, 1972): Agarose gel 1\% was prepared with Laurell-II buffer containing goat anti-guinea-pig $\mathrm{C} 3$ serum $5 \%$; this cross-reacts with mouse $\mathrm{C} 3$. A row of wells was filled with $5 \mu \mathrm{l}$ of two-fold dilutions of mouse serum; and electrophoresis was performed at $150 \mathrm{~V}$ for $8 \mathrm{~h}$.

\section{MØ-depletion (see table I)}

Silica dust. Mice were MØ-depleted by i.p. injection of $0.5 \mathrm{ml}$ of a saline suspension of sonicated silica dust $(40 \mathrm{mg} / \mathrm{ml}$; Sigma, Taufkirchen, FRG; no. 5631particle size $1-5 \mu \mathrm{m}$ diam.) at different times before infection. The silica dust had been boiled initially in $\mathrm{KOH} 5 \%$ for $15 \mathrm{~min}$, washed twice in distilled water, and heat-dried.

Dextran sulphate and Liquoid. A fresh saline solution of dextran sulphate 500 ( $5 \mathrm{mg} / \mathrm{ml}$; Serva, Heidelberg, FRG) or Liquoid $(5 \mathrm{mg} / \mathrm{ml}$; Sigma) was prepared for each experiment, the Liquoid being dissolved initially in hot saline. For MØ-depletion, mice were given i.p. injection ( $20 \mathrm{ml} / \mathrm{kg}$ of body weight) at different times before challenge.

\section{Deaths of mice after challenge}

Deaths were recorded daily for 5 days after challenge. The data (figure) represent the mean values of three experiments. Statistical significance was assessed with the unilateral four field $\chi^{2}$-test.

Table I. Substances for decomplementation or MØ-depletion of female NMRI mice

\begin{tabular}{|c|c|c|c|}
\hline Substance & Mechanism of action & Biological consequences & References \\
\hline Cobra Venom Factor & $\begin{array}{l}\mathrm{C} 3 \text { activation via the } \\
\text { alternative pathway }\end{array}$ & $\begin{array}{l}\text { C3 depletion by generating } \\
\text { C3 split products (C3a and } \\
\text { C3b) }\end{array}$ & $\begin{array}{l}\text { Cochrane et al. }(1970) \\
\text { Bitter-Suermann et al. }(1972) \\
\text { Böttger et al. (1986) }\end{array}$ \\
\hline Silica dust & $\begin{array}{l}\text { Permanent induction of the } \\
\text { "oxidative burst" in MØs } \\
\text { after phagocytosis (release of } \\
\text { lysozyme, } \mathrm{H}_{2} \mathrm{O}_{2} \text {, etc.) }\end{array}$ & Irreversible MØ-intoxication & $\begin{array}{l}\text { Allison et al. }(1966) \\
\text { du Buy (1975) } \\
\text { Bloksma et al. }(1980)\end{array}$ \\
\hline \multirow[t]{2}{*}{$\begin{array}{l}\text { Polyanions (dextran sulphate } \\
\text { and Liquoid) }\end{array}$} & $\begin{array}{l}\text { Interaction with membranes of } \\
\mathrm{M} \emptyset \text { s and inhibition of } \mathrm{Fc}- \\
\text { receptors }\end{array}$ & Inhibition of phagocytosis & Loos (1983) \\
\hline & $\begin{array}{l}\text { Activation of complement } \\
\text { (classical and alternative } \\
\text { pathway) }\end{array}$ & $\begin{array}{l}\text { Reduced activity of the } \\
\text { classical and alternative } \\
\text { complement pathways }\end{array}$ & \\
\hline
\end{tabular}




\section{Results}

\section{Virulence of $C$. jejuni in normal mice}

The LD50 of a fresh isolate of $C$. jejuni was $5 \times$ $10^{10} \mathrm{cfu}$, in a group of 32 mice infected i.p. However, after five i.p. passages, it was lowered to $10^{9} \mathrm{cfu}$. Subsequent i.p. passages did not increase the virulence any more. In a control group of 20 mice given the equivalent of $10^{9}$ heat-inactivated bacteria, there were only three deaths $(15 \%)$ significantly less than in mice challenged with live bacteria.

The influence of the route of infection was studied by injection of $5 \times 10^{8}$ cfu of $C$. jejuni which had undergone several mouse passages. Of 51 mice inoculated i.p., $13(26 \%)$ died, whereas only one $(6 \%)$ died after oral inoculation of 18 mice; therefore the i.p. route was used subsequently.

\section{Effect of CVF on serum C3 levels and infection}

Decomplementation was monitored by immunoelectrophoresis, because the murine complement system is not active in the haemolytic assay; $1 \mu \mathrm{g}$ of CVF, given i.p. $12 \mathrm{~h}$ and $24 \mathrm{~h}$ before infection, reduced the $\mathrm{C} 3$ concentration to below $5 \%$ of normal. Exact determination of lower levels of C3 was not possible by electrophoresis, because of the insensitivity of this method. With the intention of achieving maximum decomplementation, all animals were given $2 \times 5 \mu \mathrm{g}$ of $\mathrm{CVF}$ in subsequent experiments.

The in-vitro serum sensitivity of $C$. jejuni was assessed by inoculating $90 \%$ mouse-serum with bacteria to give a final concentration of $10^{4} \mathrm{cfu} / \mathrm{ml}$. After $2 \mathrm{~h}$, the recovery from normal serum was only $600 \mathrm{cfu} / \mathrm{ml}$, indicating $94 \% \mathrm{killing}$. However, serum of CVF-treated mice exerted no bactericidal effect; after $2 \mathrm{~h}$, the recovery from decomplemented serum was $1.1 \times 10^{4} \mathrm{cfu} / \mathrm{ml}$.

For 28 decomplemented mice that were challenged i.p. with $5 \times 10^{8} \mathrm{cfu}$, the mortality at day 5 was $21 \%$ (figure) and was similar to that after challenge of untreated controls. Moreover, CVFtreated controls, that were not challenged with $C$. jejuni, showed no overt signs of disease.

\section{Effect of silica on infection}

MØ-depletion was induced by i.p. injection of sonicated silica dust $(20 \mathrm{mg} / \mathrm{mouse})$. The influence of the interval between this treatment and subsequent challenge is shown in table II: the highest mortality was found when silica was given $2.5 \mathrm{~h}$ before challenge, so this interval was used in subsequent experiments. Silica had little effect when given $8 \mathrm{~h}$ before challenge.

Challenge of 28 silica-treated mice resulted in a mortality of $64 \%$, compared with $25 \%$ of the untreated controls (figure). The difference was statistically significant from day 2 to day 5 $(p<0.05)$. Silica-treated controls, that were not challenged with $C$. jejuni, showed no signs of disease.

Table II. Influence of time-interval between MØ-depletion and bacterial challenge: mice were challenged i.p. with $5 \times 10^{8}$ cfu of $C$. jejuni

\begin{tabular}{|c|c|c|c|c|c|}
\hline \multirow{2}{*}{$\begin{array}{l}\text { MØ-depletion by } \\
\text { prior i.p. injection } \\
\quad(\text { at } 0 \text { h) of }\end{array}$} & \multicolumn{5}{|c|}{$\begin{array}{l}\text { Number of mice dead within } 5 \text { days per } \\
\text { total number challenged after a time- } \\
\text { interval of }\end{array}$} \\
\hline & $0 \mathrm{~h}$ & $2 \cdot 5 \mathrm{~h}$ & $5 \mathrm{~h}$ & $8 \mathrm{~h}$ & $26 \mathrm{~h}$ \\
\hline Silica dust & $4 / 10$ & $6 / 10$ & $3 / 10$ & $1 / 8$ & ND \\
\hline Dextran sulphate & $12 / 20$ & $13 / 20$ & $8 / 20$ & $4 / 20$ & $3 / 20$ \\
\hline Liquoid & $5 / 9$ & $6 / 9$ & $3 / 9$ & $2 / 9$ & $0 / 9$ \\
\hline
\end{tabular}

$\mathrm{ND}=$ not done.

\section{Effect of polyanions on infection}

MØ-inhibition was accomplished by i.p. injection of dextran sulphate or Liquoid $(100 \mathrm{mg} / \mathrm{kg}$ of body weight). As with silica, these were most effective when injected $2.5 \mathrm{~h}$ before challenge (table II).

After previous treatment with dextran sulphate, the mortality in a group of 33 challenged mice was $58 \%$ (figure); and a similar mortality $(52 \%)$ was observed in the same number of Liquoid-treated mice. With dextran sulphate, the mortality was raised significantly from day 2 to day $5(\mathrm{p}<0.05)$, but only on day 5 in Liquoid-treated mice. After either form of treatment, controls that were not challenged with $C$. jejuni displayed no signs of disease.

\section{Effect of combined CVF and silica on infection}

Mice were decomplemented and MØ-depleted simultaneously by injecting CVF and silica before challenge. With 24 such mice, the mortality at day 5 was $54 \%$ (figure); and it was significantly greater than with untreated controls from day 3 to day 5 $(p<0.05)$. However, there was no significant difference between mice treated with silica alone and those treated with both CVF and silica. 


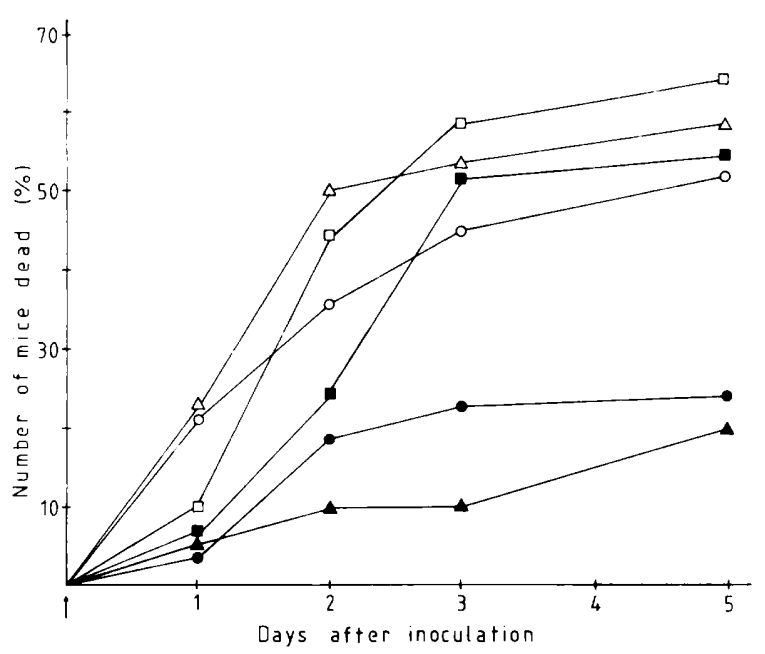

Figure. Effect of MØ-depletion and decomplementation on mortality of mice in i.p. inoculation at day $0(\uparrow)$ with $5 \times 10^{8} \mathrm{cfu}$ of $C$. jejuni. Compared with untreated controls ( $)$, MØdepleted mice showed a significant increase in mortality $(\mathrm{p}<$ 0.05 ), from day 2 to day 5 if pre-treated with silica $(\square)$ or dextran sulphate $(\triangle)$, but only at day 5 with Liquoid $(O)$. Mice decomplemented with CVF ( $\mathbf{\Delta}$ ) showed no significant difference from controls. Combined pre-treatment with CVF and silica (ם) resulted in a significant increase in mortality from day 3 to day 5 , similar to that with silica alone.

\section{Discussion}

Although $C$. jejuni is not very pathogenic for mice or other animals when given orally, after i.p. inoculation animals show signs of disease such as diarrhoea and weight-loss which mimic campylobacteriosis in man (Madge, 1980; Blaser et al., 1985). The present study has also confirmed the finding of Kazmi et al. (1984) that virulence may be enhanced by multiple animal passage. Moreover, the isolate used in this study was sensitive to mouse serum, a result similar to that of Blaser et al. (1985) who found that strains of $C$. jejuni were sensitive to human serum.

To study the role of complement in host defence, mice were treated with CVF; serum-C3 decreased by more than $95 \%$. A higher degree of decomplementation could not be demonstrated electrophoretically, because of insensitivity of this method. However, it might be assumed that $\mathrm{C} 3$ levels fell below $1 \%$ of normal, as shown by reports of studies with other rodents (Böttger et al., 1986). Nevertheless, after i.p. challenge with the serum-sensitive strain of $C$. jejuni, these decomplemented mice showed the same mortality as mice with an intact complement system (figure).

In other experiments (data not shown), mice were pre-treated with a venom from Pseudomyrmex triplarus, which impairs specifically the classical pathway (Schultz and Arnold, 1977). The infection after subsequent challenge was no different from that in controls or CVF-treated mice. In further experiments (data not shown), inbred AJ or DBA2 mice, which are known to have a genetic C5 deficiency, were challenged with the same strain. No significant increase in mortality was detected, indicating no major role for the cytolytic terminal complex of the complement system in this type of infection.

The decomplementation experiments suggest that normal levels of serum complement are not essential for the resistance of mice to $C$. jejuni infection, despite the susceptibility of the organism to the bactericidal activity of serum in vitro. However, it could be argued that residual C3 was sufficient in the decomplemented animals.

To study the role of the MØ in host defence, $\mathrm{M} \varnothing$ activity was impaired by pre-treatment of mice with silica or with polyanions (dextran sulphate or Liquoid) to intoxicate $\mathbf{M}$ s or to inhibit their phagocytic activity (table I). In each case, pretreated mice showed a significant increase in mortality after challenge with $C$. jejuni, compared with untreated controls (figure). The effect of MØdepletion was detectable only when the interval between treatment and challenge was no more than $5 \mathrm{~h}$, presumably because of recruitment of more MØs. Moreover, the results showed no difference between silica treatment, which is directed mainly against $\mathrm{M} \emptyset \mathrm{s}$, and polyanion treatment, which affects the complement system also. Furthermore, the combined effect of silica and CVF resembled that of silica alone, not that of CVF (figure), suggesting that decomplementation does not add to the effect of silica treatment.

This study was not intended to determine which bacterial virulence factors were responsible for disease. Previous workers have shown an endotoxin-mediated effect, using a larger inoculum $\left(>10^{9} \mathrm{cfu}\right)$ and younger mice than in this study ( $\mathrm{Ng}$ et al., 1980). Because of the large inoculum, lipopolysaccharide (LPS) might be involved in the pathogenic process.

However, additional factors are probably involved too, because silica-treated mice that received heat-inactivated bacteria showed a significantly lower mortality than those that received the same number of live bacteria (data not shown). Furthermore, $\mathrm{C} 3 \mathrm{H} / \mathrm{HeJ}$ mice, which are genetically insusceptible to the action of LPS, showed no increase in resistance to the experimental campylobacter infection (data not shown).

The present results indicated that $M \varnothing s$ are an 
important factor in the defence of mice against campylobacter infection, whereas non-specific humoral factors appear to play no important role. However, opsonisation might be mediated by crossreacting immunoglobulins which are directed against other gram-negative bacilli (Perez-Perez et al., 1986). The involvement of mononuclear cells in mice is further supported by in-vitro studies, which

\section{REFERENCES}

Allison A C, Harington J S, Birbeck M 1966 An examination of the cytotoxic effects of silica on macrophages. Journal of Experimental Medicine 124: 141-154.

Banfi E, Cinco M, Zabucchi F 1986 Phagocytosis of Campylobacter jejuni and $C$. coli by peritoneal macrophages. Journal of General Microbiology 132:2409-2412.

Bitter-Suermann D, Dierich M, König W, Hadding U 1972 Bypass-activation of the complement system starting with C3. Immunology 23: 267-281.

Blaser M J, Duncan D J, Warren G H, Wang W L 1983 Experimental Campylobacter jejuni infection of adult mice. Infection and Immunity 39:908-916.

Blaser M J, Smith P F, Kohler P F 1985 Susceptibility of Campylobacter isolates to the bactericidal activity of human serum. Journal of Infectious Diseases 151 :227-235.

Bloksma N, de Reuver M J, Willers J M 1980 Influence on macrophage functions as a possible basis of immunomodifications by polyanions. Annales d'Immunologie 131 D : 255265.

Böttger E C, Hoffman T, Metzger S, Hadding U, BitterSuermann D 1986 The role and mechanism of Cobra Venom Factor-induced suppression of the humoral immune response in guinea pigs. Journal of Immunology 137:12801285.

du Buy H 1975 Effect of silica on virus infections in mice and mouse tissue culture. Infection and Immunity 11:996-1002.

Cochrane C G, Müller-Eberhard H J, Aikin B S 1970 Depletion of plasma complement in vivo by a protein from Cobra Venom: its effect on various immunological reactions. Journal of Immunology 105 : 55-69.

Duffy M C, Benson J B, Rubin S J 1980 Mucosal invasion in campylobacter enteritis. American Journal of Clinical Pathology 73: 706-708.

Fox J G 1982 Campylobacteriosis-a "new" disease in laboratory animals. Laboratory Animal Science 32 : 625-637. showed phagocytosis of $C$. jejuni and intracellular survival in mononuclear phagocytes (Kiehlbauch et al., 1985; Banfi et al., 1986). Additional evidence for the role of $M \varnothing s$ in campylobacter infection was provided by electronmicroscopy studies, which demonstrated the presence of phagocytic cells in the intestinal mucosa after experimental infection (Duffy et al., 1980).

Humphrey C D, Montag D M, Pittman F E 1986 Morphologic observations of experimental Campylobacter jejuni infection in the hamster intestinal tract. American Journal of Pathology 122: 152-159.

Kazmi S U, Roberson B S, Stern N J 1984 Animal passed, virulence-enhanced Campylobacter jejuni causes enteritis in neonatal mice. Current Microbiology 11 : 159-164.

Kiehlbauch J A, Albach R A, Baum L L, Chang K P 1985 Phagocytosis of Campylobacter jejuni and its intracellular survival in mononuclear phagocytes. Infection and Immunity 48:446-451.

Laurell C B 1972 Electroimmuno assay. Scandinavian Journal of Clinical and Laboratory Investigation 29 Suppl 124:21-23.

Loos M 1983 Biosynthesis of the collagen-like Clq molecule and its receptor functions for $\mathrm{Fc}$ and polyanionic molecules in macrophages. Current Topics in Microbiology and Immunology 102 : 1-56.

Madge D S 1980 Campylobacter enteritis in young mice. Digestion 20:389-394.

McCardell B A, Madden J M, Stanfield J T 1986 A mouse model for the measurement of virulence of species of Campylobacter. Journal of Infectious Diseases 153:177.

Ng F K P, Wardlaw A C, Stewart-Tull D E S 1980 Enhancement of the lethal effect of Campylobacter fetus ssp. jejuni in sevenday old mice by ferric ammonium citrate. Society for General Microbiology Quarterly 8:12.

Perez-Perez G I, Hopkins J A, Blaser M J 1986 Lipopolysaccharide structure in Enterobacteriaceae, Pseudomonas aeruginosa and Vibrio cholerae are immunologically related to Campylobacter spp. Infection and Immunity 51 : 204-208.

Schultz D R, Arnold P I 1977 Venom of the ant Pseudomyrmex $\mathrm{sp}$.: further characterisation of two factors that affect human complement proteins. Journal of Immunology 119:1690-1699.

Skirrow M B 1977 Campylobacter enteritis: a "new" disease. British Medical Journal 2:9-11. 